\title{
Mandatory Social Distancing for Covid-19 Outbreak and Its Economic Consequences in West Sumatera - Indonesia
}

\section{Efektifitas PSBB dalam Menurunkan Laju Penularan Covid-19 dan Hubungannya dengan Ekonomi Sumatera Barat - Indonesia}

\author{
Endrizal Ridwan ${ }^{1}$, Besti Novianda ${ }^{1}$ \\ ${ }^{1}$ Departement of Economics, Universitas Andalas
}

Correspondence: Endrizal Ridwan

E-mail: eridwan@eb.unand.ac.id

\begin{abstract}
The Governor of West Sumatra Province of Indonesia imposed a mandatory social distancing (PSBB) to slow down the Covid-19 outbreak from 22 April to 7 June 2020. The cons argued that PSBB was ineffective because of the impossibility to limit people's movements. The pros, on the other hand, viewed PSBB as a training facility to increase people's awareness about the pandemic. Our research aims at evaluating the effectiveness of PSBB by using the Kermack-McKendrick SIR pandemic model and the NLSUR non-linear least square estimation. Using daily data published by the Covid-19 task force, we found that PSBB had a positive impact on flattening the curve. Assuming that vulnerable people were around $30 \%$ of the population, PSBB has reduced the rate of spread of Covid-19 from around 2 persons to less than 1 person for every infected. We also found that the economic consequences of PSBB on commodities varied by their demand and supply characteristics. We, therefore, suggest that policy interventions related to price control and subsidy should consider these characteristics. For future research, as data more available, the effect of PSBB on broader economic variables such as poverty and growth in the province needs to be examined. Keywords: Mandatory Social Distancing, Kermack-McKendrick's SIR Model, Non-Linear Least Square, West Sumatera
\end{abstract}

\section{Abstrak}

Gubernur Provinsi Sumatera Barat memberlakukan kewajiban pembatasan sosial berskala besar (PSBB) untuk memperlambat penyebaran wabah Covid-19 dari 22 April hingga 7 Juni 2020. Banyak yang kontra dan menilai PSBB tidak efektif karena kesulitan membatasi pergerakan orang selama PSBB. Di sisi lain, kalangan yang pro menilai PSBB perlu dilihat sebagai sarana latihan bagi masyarakat untuk meningkatkan kesadaran tentang penyebaran virus. Penelitian kami mengevaluasi efektivitas PSBB dengan menggunakan model matematika standar Kermack-McKendrick SIR dan menggunakan estimasi kuadrat terkecil non-linier NLSUR. Dengan menggunakan data harian yang diterbitkan oleh satuan tugas COVID-19, kami menemukan bahwa PSBB secara signifikan berdampak positif dalam menurunkan laju penyebaran virus. Dengan asumsi penduduk rentan sekitar 30\% dari populasi, PSBB telah menurunkan angka penyebaran COVID-19 dari sekitar 2 orang menjadi kurang dari 1 orang untuk setiap kasus terkonfirmasi positif. Kami juga menemukan bahwa konsekuensi ekonomi dari penerapan PSBB terhadap komoditi bergantung kepada karakteristik permintaan dan penawarannya. Karena itu kami merekomendasikan kebijakan harga dan subsidi mesti berpedoman kepada karakteristik tersebut. Untuk penelitian lanjut, dengan semakin tersedianya data, penelitian tentang dampak PSBB terhadap variabel ekonomi yang lebih luas seperti kemiskinan dan pertumbuhan di provinsi ini urgen dilakukan.

Kata kunci: Pembatasan Social Berskala Besar (PSBB), Kermack-McKendrick's SIR Model, Non-Linear Least Square, Sumatera Barat

\section{Introduction}

On April 22, 2020, the Governor of West Sumatra enacted mandatory social distancing or large-

scale social restrictions (hereafter PSBB) based on the Regulation of the Health Minister of 
Republic Indonesia and Governor Regulation concerning PSBB Guidelines in West Sumatra. PSBB was enforced from April 22, 2020, to June 7, 2020. PSBB aimed at limiting public activities to control the spread of Covid-19. Academicians estimated that around 350 thousand people in West Sumatra were potential to be exposed to Covid-19 and it was also possible that the pandemic may reoccur in the future because of the difficulties to end the pandemic (Djafri, 2020). Until May 17, 2020, the number of positive Covid-19 has reached 408 people in West Sumatra, up from 81 people when the PSBB was initially implemented (www.corona.sumbarprov.go.id, 2020). Many argued that PSBB was ineffective because people still free to do their activities. Some others argued that PSBB could not just be seen from a drastic decline in public activities but rather as a training facility for the public to care about the spread of the virus (Djafri, 2020). The fact that an increase in positive cases from 81 to 408 could not be the reason for claiming the ineffectiveness of PSBB because counterfactual data were unavailable.

Our research tries to evaluate the effectiveness of PSBB using the level of spread of COVID-19 by using daily data published by West Sumatran taskforce's website of www.corona.sumbarprov.go.id We used the standard mathematical pandemic model of the Susceptible-Infective-Remove (SIR), which was invented by Kermack and McKendrick (1927). This model allows us for conducting studies on the impact of public policies such as vaccine findings, quarantine, and social restrictions like PSBB (Martcheva, 2015; Li, 2018).

Our study used the modification of the SIR pandemic model as in Chudik, Pesaran, and Rebucci (2020) to analyze the PSBB effect. Chudik, Pesaran, and Rebucci (2020) found that the implementation of PSBB was very effective in flattening the pandemic curve at the beginning of the pandemic period, but its negative impact on the economy was very large in terms of unemployment. In a separate study, Acemoglu, Chernozhukov, Werning, and Whinston (2020) found that strict and long PSBB targeted to the most vulnerable groups reduced infection and allows a less stringent PSBB to be implemented for low-risk groups. Overall, targeted policies combined with measures to reduce interaction between groups, mass testing, and self-isolation could minimize economic loss and mortality.

We also examined the impact of PSBB on the economy of West Sumatra. Restrictions on socioeconomic activities resulted in a decreased productivity and increased unemployment. Annette, Bratsberg, Eielsen, Kopczuk, Markussen, Raaum, \& Roed (2020) found that the effects of PSBB were rapidly spreading to industries that were not directed affected by the policy. Their study identified that nearly $90 \%$ of companies implemented temporary layoffs, although that changed during the crisis. They found that the Covid-19 shock hit the vulnerable population and the less productive and financially weak companies. In addition, Mongey, Pilossoph, and Weinberg (2020) found that companies that placed fewer workers with work from home (WFH) status before the pandemic experienced relatively small contraction when forced by WFH. Aum, Lee, and Shin (2020) show that low-skilled and self-employed workers were the most disadvantaged groups affected by the pandemic and government policies.

The main objective of our research is to examine the effectiveness of PSBB in reducing the rate of transmission of COVID-19 in West Sumatra and to relate the implementation of PSBB to the economic conditions of West Sumatra. This research is urgent because PSBB must be assessed validly and objectively, not only as an opinion. The result will help the Regional Government of West Sumatera and other related agencies to continue or terminate PSBB as a prevention tool of COVID-19 transmission. 


\section{Method}

We used the mathematical model of pandemic introduced by Kermack dan McKendrick (1927) known as the suspicious-infectious-recovery
(SIR) model. For the estimation purposes, we modified the discrete version of the SIR model in Kocik dan Ladas (1993), which consisted of three systems of difference equations:

$$
\left.\begin{array}{c}
S_{t+1}=e^{-\left(\alpha+\delta D \operatorname{PSBB}_{t}\right) I_{t}} S_{t} \\
I_{t+1}=I_{t}+\left(1-e^{-\left(\alpha+\delta D P S B B_{t}\right) I_{t}}\right) S_{t} \\
R_{t+1}=(1-\beta) I_{t}+R_{t}
\end{array}\right\} t=0,1,2, \cdots
$$

where, $\alpha+\delta \in(0, \infty)$ and $\beta \in(0,1)$.

The variable $S_{t}$ refers to the number of populations who are susceptible to COVID-19 in a period $t$, the variable $I_{t}$ is the number of infected persons in a period $t$, and the variable $R_{t}$ is the number of those who are immune, recovered, or deceased in a period $t . D P S B B_{t}$ is a dummy variable for the period of mandatory social distancing. We assume that $S_{0}, I_{0} \in(0, \infty)$ and $R_{0}=0$, which means that at the beginning of the period, some individuals were infected and none were immune or recovered. The first row of equation (1) implies that $S_{t}$ always decreases, the third row implies that $R_{t}$ always increases, and $I_{t}$ approaches zero at the end of a pandemic. The other assumption was a constant population that made the equation $S_{0}+I_{0}=S_{t}+I_{t}+R_{t}$ hold for all time.

With $D P S B B_{t}$ equals 1 , iterating the first row of equation (1) yields

$$
S_{t}=\exp \left[-(\alpha+\delta) \sum_{i=0}^{t-1} I_{i}\right] S_{0}
$$

and using an iteration from the third row of equation (1) and the fact that $R_{0}=0$ produces

$$
S_{t}=\exp \left(-\frac{\alpha}{1-\beta} R_{t}\right) S_{0} \text {. }
$$

By using the logarithmic function for equation (3) and substituting $R_{t}$ from the third row of equation (1) we get the connecting equation of the number of susceptible individuals with the number of infected people and the number of recoveries. Then, after inserting the variable of $D P S B B_{t}$ back into the equation, the connecting equation becomes:

$$
\log S_{t}=\log S_{0}-\left(\alpha+\delta D P S B B_{t-1}\right) I_{t-1}-\frac{\left(\alpha+\delta D P S B B_{t-1}\right)}{1-\beta} R_{t-1}
$$

The parameters to be estimated are $\alpha, \beta$, and $\delta$. The parameter $\alpha$ shows the rate of virus transmission, $1-\beta$ represents the recovery rate, and the parameter $\delta$ represents the effectiveness of PSBB. These parameters were estimated using non-linear seemingly unrelated regressions (NLSUR) and using a linear system of equation (REG3) for the robustness check with the help of STATA software.
The second objective of our study was to determine the impact of PSBB on the West Sumatran economy. We analyzed the fluctuation of selected commodity prices before, during, and after PSBB. We chose the commodities with a specific character in their demand and supply. We then conducted a simple $t$-test to compare their price during PSBB time to that of before-after PSBB to check if the price varied significantly. 
The population of the study is those who are vulnerable with three categories. They are susceptible, measured by the number of vulnerable populations in the area, infectious, measured by the number of confirmed positive COVID-19, and removes, measured by the number of patients recovered or died. The concept of sampling techniques in this study was irrelevant because the research objective was not to generalize but to estimate the relevant coefficients. The data used in this study are secondary data published by relevant government agencies. We collected data from March 1, 2020, to September 30, 2020, which included the period before, during, and after PSBB was enacted. The PSBB, as stated above, was in effect from April 22, 2020, to June 7, 2020. To see the relationship between the implementation of PSBB on the economy of West Sumatra, we analyzed the movement of passenger arrivals at BIM International Airport Padang and prices of 10 strategic food commodities at four major traditional markets in two major cities, Padang and Bukittinggi, to represent the economy of West Sumatra. We collected data on Covid-19 from the Department of Communication and Informatic Padang City, data on Airport passengers from Statistics of Sumatera Barat Province, and data on food commodities from the National Center for Strategic Food Prices. We used a simple pairwise $t$-test to see whether PSBB had an impact on prices.

\section{Findings}

This research used published data from relevant public agencies from March 1, 2020, to September 30, 2020. The observed variables include the number of positive confirmed cases of COVID-19, the number of cures and deaths, the number of passenger arrivals, and the prices of strategic food commodities. Figure 1 shows the number of infectious, removal, and passenger arrivals from March, 1 to September 30, 2020. The number of observations was 214. The susceptible were assumed to be $30 \%$ of the total 2020 population of West Sumatra, amount to $5,498,751$ people. The first infected case was recorded on March 26, 2020. The maximum number of infectious in one day was 2,974 cases on September 29, 2020. At the end of the analysis period, the number of people who recovered and died had accumulated as many as 3,312 cases.

Figure 1. West Sumatra: Number of Infectious, Removes, and Arrival (March 1 - September 30, 2020)

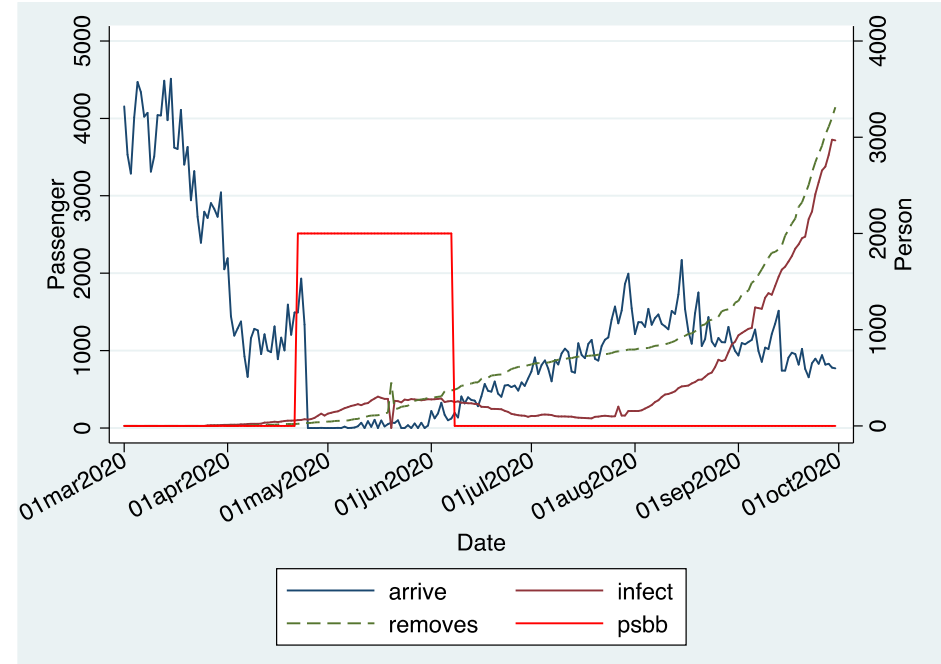

Source: COVID-19 Task Force and Department of Transportation 
At the early stage of the pandemic in West Sumatra, imported cases were blamed to be the source of spreads, and air travel was the prime suspect. During the data period, the number of arrivals averaged around 2,100 passengers per day with a maximum value of 4.511 and a minimum value of 0 , which occurred during the PSBB period. We tested whether the number of arrivals contributes to the positive cases before the PSBB was implemented. The null of a positive correlation coefficient between the two was firmly rejected. The correlation coefficient was -0.7. While it was true that the first case was an imported case, the claim that air travel increased the number of infectious was not supported by data. The main source of spread was, therefore, a local or interregional transmission other than air travelers.

Table 1. The Estimates for the Coefficients of Parameters

\begin{tabular}{lll}
\hline Parameter & NLSUR Estimates & REG3 Estimates \\
\hline Alpha $\alpha$ & $1.47 \times 10^{-6 * * *}$ & $1.77 \times 10^{-6 * * *}$ \\
& $\left(1.46 \times 10^{-8}\right)$ & $\left(7.39 \times 10^{-8}\right)$ \\
Delta $\delta$ & $-1.01 \times 10^{-6 * * *}$ & $-7.55 \times 10^{-7 * *}$ \\
& $\left(9.01 \times 10^{-8}\right)$ & $\left(3.07 \times 10^{-7}\right)$ \\
Beta $\beta$ & $.9608 * * *$ & $.9609 * * *$ \\
& $(.0011)$ & $(.0013)$ \\
Alpha + Delta $(\alpha+\delta)$ & $4.60 \times 10^{-07 * * *}$ & $1.02 \times 10^{-6 * * *}$ \\
& $\left(8.89 \times 10^{-08}\right)$ & $\left(3.01 \times 10^{-7}\right)$ \\
\hline
\end{tabular}

Note: the standard error is in the bracket.

$* * *=1 \%$ significance level, $* *=5 \%$ significance level, and $*=10 \%$ significance level.

As the main objective of our study was to examine the effectiveness of the PSBB in reducing the rate of spread of the Covid-19 virus in West Sumatra, we estimated the coefficients of alpha, beta, and gamma from equation (1) by both nonlinear and linear system of equations. Table 1 presents the estimates of those coefficients by nonlinear seemingly unrelated regression (NLSUR) and linear system of equation (REG3). The NLSUR model of equation (1) showed that PSBB had a positive impact on reducing the rate of spread of the virus. The delta coefficient of $1.03 \mathrm{e}-06$ and significant proved that PSBB reduced the spread rate by this magnitude. In addition, this model also estimated that the rate of virus spread, the alpha coefficient, in which without PSBB it was around 1.47e-06 and dropped to 4.60e-07 during PSBB. The model also estimated that the coefficient beta was around 0.96 which implied that the rate of recovery or removal was around $4 \%$ of the stock of confirmed positive cases. Thus, after inserting the coefficients in Table 1 into equation (1) and (4) we get.

$$
\left.\begin{array}{c}
S_{t+1}=e^{-\left(1.47-1.01 D P S B B_{t}\right) 10^{-6} I_{t}} S_{t} \\
I_{t+1}=0.96 I_{t}+\left(1-e^{-\left(1.47-1.01 D P S B B_{t}\right) 10^{-6} I_{t}}\right) S_{t} \\
R_{t+1}=0.04 I_{t}+R_{t}
\end{array}\right\} t=0,1,2, \cdots
$$

and

$$
\log S_{t}=\log S_{0}-\left(1.47-1.01 D P S B B_{t-1}\right) 10^{-6} I_{t-1}-\frac{\left(1.47-1.01 D P S B B_{t-1}\right) 10^{-6}}{0.04} R_{t-1}
$$


We used the REG3 model of estimation for a robustness check. The estimates from the REG3 model confirmed the results of the significant contribution of the PSBB on reducing the virus spread. The coefficient delta, albeit slightly different from that of NLSUR, was the same sign and statistically significant. Furthermore, the REG3 estimated beta of 0.9609 was close to that of NLSUR. Therefore, the claim that the PSBB flattened the curve was robust to a change in modeling.

Figure 2. West Sumatra: Price Movement of Selected Strategic Food (Rp/kg)

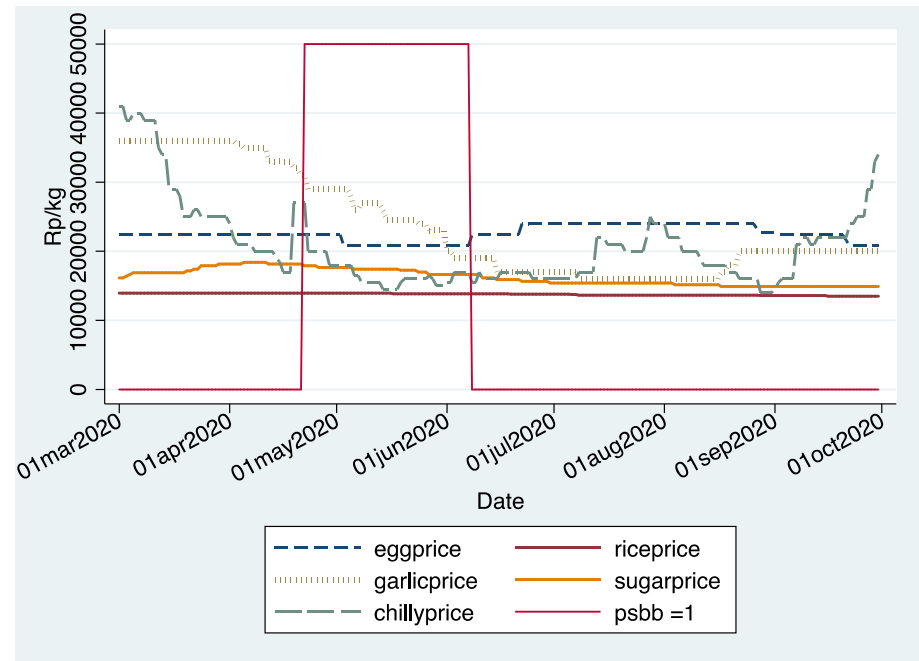

Source: National Center for Strategic Food Prices

The relationships of PSBB and the West Sumatran economy were analyzed through changes in commodity prices before, during, and after PSBB. We chose 10 strategic food commodities that have a significant contribution to inflation especially volatile food inflation, taken from the National Center for Food Price Information. Figure 2 shows the daily price of selected strategic commodities of rice, chicken eggs, chilies, garlic, and sugar from March 1 to September 30, 2020. The selected commodities have their respective characteristics in terms of demand and supply. The interaction of demand and supply formed a price pattern for each commodity.

Table 2. Commodity Price Difference Between In and Out PSBB Period

\begin{tabular}{|c|c|c|c|}
\hline Commodity & $\begin{array}{ll}\text { Price } & \text { difference } \\
(\mathrm{Rp} / \mathrm{kg}) & \end{array}$ & Commodity & $\begin{array}{ll}\begin{array}{l}\text { Price } \\
(\mathrm{Rp} / \mathrm{kg})\end{array} & \text { difference } \\
\end{array}$ \\
\hline Rice & $\begin{array}{l}-268.7^{* * * *} \\
(31.1)\end{array}$ & Garlic & $\begin{array}{l}-4,599.6 * * * \\
(1,315.6)\end{array}$ \\
\hline Chicken & $\begin{array}{l}-1145.5^{* * *} \\
(667.7)\end{array}$ & Chili & $\begin{array}{l}5,252.1 * * * \\
(846.9)\end{array}$ \\
\hline Meat & $\begin{array}{l}324.3^{* *} \\
(173.5)\end{array}$ & Pepper & $\begin{array}{l}4,707.1 * * * \\
(632.1)\end{array}$ \\
\hline Egg & $\begin{array}{l}1,308.7 * * * \\
(104.6)\end{array}$ & Cooking Oil & $\begin{array}{l}196.2 * * * \\
(54.7)\end{array}$ \\
\hline Onion & $\begin{array}{l}-1,5951.9 * * * \\
(779.9)\end{array}$ & Sugar & $\begin{array}{l}-1,388.6^{* * *} \\
(186.0)\end{array}$ \\
\hline
\end{tabular}

Note: the standard error is in the bracket.

$* * *=1 \%$ significance level, $* *=5 \%$ significance level, and $*=10 \%$ significance level. 
We used a simple $t$-test to analyze the differences in commodity prices during the PSBB period and outside the PSBB period. Table 2 shows the results from $t$-test for all 10 strategic food commodities. The prices of rice, chicken, onion, garlic, and sugar during the PSBB period were higher significantly than their prices during the non-PSBB period. This price difference could be attributed to their less availability during the PSBB, one of which was due to transportation restrictions despite the government's insisted that there were no restrictions for basic needs. Although their demand decreased due to the pandemic, their supply decreased even deeper.

Meanwhile, the prices of meat, eggs, chili, paper, and cooking oil during the PSBB were lower than their prices during the non-PSBB period. This phenomenon confirmed a decrease in demand during the PSBB period: people reduced their consumption because they stay at home, while the producers had no choice other than to keep selling their products as production was relatively constant. The reduction in consumption was also likely due to a contraction in the culinary sector, where these commodities were the main raw materials. In this case, the decrease in demand dominates the decrease in supplies so the price dropped during the PSBB.

\section{Discussion}

The NLSUR model of equation (1) showed that PSBB had a positive impact on reducing the rate of spread of the virus. This model estimated that the rate of virus spread, the alpha coefficient, in which without PSBB it was around 1.47e-06 and dropped to $4.45 \mathrm{e}-07$ during PSBB. The delta coefficient of $1.03 \mathrm{e}-06$ and significant proved that PSBB reduced the spread rate by this magnitude. Assuming 30\% of West Sumatra's population were susceptible and the number of infectious 3000, PSBB had successfully dropped the spread of the virus from 2 new cases to less than 1 new case for every infectious. In other words, PSBB lowered the rate of infectious from $.44 \%$ to $.13 \%$ calculated from the number of infectious per susceptible. In addition, the model also estimated that the coefficient beta was around 0.96 which implied that the rate of recovery or removal was around $4 \%$ of the stock of confirmed positive cases.

The economic impact of PSBB on the local economy can be seen from the movement of basic commodity prices. Commodities whose demand and supply are relatively easy to adjust tended to have a stable price; commodities with a relatively constant demand but short in supply tended to have a price jump during PSBB; and those with a relatively sticky supply tended to have a drop in prices. Therefore, our study suggests that government intervention related to price controls and subsidies during pandemic-like disasters cannot be generalized for all commodities; policymakers need to pinpoint characteristics of commodities before implementing a designated policy. For instance, for the commodities whose supplies are hard to adjust while their demands are easy, pandemics tend to harm suppliers more than customers so thus attention should be focused on suppliers. Meanwhile, for the commodities whose demand are relatively hard to adjust, pandemic hurt customers more than suppliers so thus government attention should be focused to strengthen customer purchasing power.

\section{Conclusion}

SIR model using the non-linear least square NLSUR method showed that PSBB had a positive impact on reducing the rate of spread of the virus. The delta coefficient, which was $1.03 \mathrm{e}-$ 06 and significant, proved that PSBB reduced the rate of virus spread by this order of magnitude. In addition, the model also estimated the rate of spread itself without PSBB was around 1.47e-06. As a consequence, with an assumption of the number of vulnerable people around $30 \%$ of the 
total population of West Sumatra, PSBB reduced the rate of spread from around 2 people to less than 1 person for every positive infected population. This model also showed that the recovery or removal rate was around $4 \%$ of the stock of confirmed positive cases. The results were robust to the change in calculation methods since the alternative model of REG3 also supported the conclusion. Thus, we were able to provide answers to the research questions of the effectiveness of PSBB by showing that PSBB was indeed effective.

\section{Acknowledgement}

We thank the Faculty of Economics Universitas Andalas for the provided research grant (Contract number 35/UN.16.5/FEUA/2020) and anonymous assistants for collecting data. All errors are ours.

\section{Declaration}

We certify that we have no affiliations with or involvement in any organization or entity with any financial or non-financial interest in the materials discussed in this manuscript.

\section{References}

Acemoglu, D., Chernozhukov, V., Werning, I., Whinston, M. 2020. A Multi-Risk SIR Model with Optimally Targeted Lockdown. NBER Working Paper No. 27102.

Annette, A., Bratsberg, B., Eielsen, G., Kopczuk, W., Markussen, S., Raaum, O., Røed, K. 2020. The First Weeks of the Coronavirus Crisis: Who Got Hit, When and Why? Evidence from Norway. NBER Working Paper No. 27131.

Aum, S., Lee, S., Shin, Y. 2020. Inequality of Fear and Self-Quarantine: Is There a Tradeoff between GDP and Public Health? NBER Working Paper No. 27100.

Badan Pusat Statistik Provinsi Sumatera Barat. 2020. Data Jumlah Penumpang Angkutan
Udara. $30 \quad$ September $2020<$ https://sumbar.bps.go.id >

Chudik, A., Pesaran, M., Rebucci, A. 2020. Voluntary and Mandatory Social Distancing: Evidence on COVID-19 Exposure Rates from Chinese Provinces and Selected Countries. NBER Working Paper No. 27039.

Djafri, D. 2020. Bermain Cik-Mancik (Playing Hide and Seek) COVID-19: Bukti, Masalah, dan Strategi Pengendalian COVID-19. Diskusi Online WAG Kawal Covid-19 Sumbar Series 5: Gagasan Baru Penanganan Covid-19 di Sumbar: Pendekatan Revolusioner dan Progresif [Webinar 17 June 2020]. 1 July 2020 <https://youtu.be/pJcE_iE7oEc >

Dinas Komunikasi dan Informatika Pemerintah Kota Padang. 2020. Covid19 Provinsi Sumatera Barat Dalam Angka. 30 September 2020.

<http://corona.padang.go.id/index.php/kondis i-sumatera-barat>.

Goldfarb, A., Tucker, C. 2020. Which Retail Outlets Generate the Most Physical Interactions? NBER Working Paper No. 27042.

Kermack, W., McKendrick, A. 1927. A Contribution to the Mathematical Theory of Epidemics. Proceedings of the Royal Society of London. Series A, Containing Papers of a Mathematical and Physical Character, Vol. 115, No. 772 (Aug. 1, 1927), pp. 700-721.

Kocik, V., Ladas, G. 1993. Global Behavior of Nonlinear Difference Equations of High Order with Applications. Kluwer Academic Publishers.

Li, M. 2018. An Introduction to Mathematical Modeling of Infectious Diseases. Springer.

Martcheva, M. 2015. An Introduction to Mathematical Epidemiology. Springer.

Mongey, S., Pilossoph, L., Weinberg, A. 2020. Which Workers Bear the Burden of Social 
Distancing Policies? NBER Working Paper No. 27085.

Pusat Informasi Harga Pangan Strategis Nasional (PIHPSN). 2020. Tabel Harga Berdasarkan Komoditas. 30 September 2020. <

https://hargapangan.id/tabel-harga/pasartradisional/komoditas>.

Sumbar Tanggap Corona (2020). Data Pantauan COVID-19 Provinsi Sumatera Barat. 1 October 2020

<https://corona.sumbarprov.go.id/web> 